may be seen in the duration of antiepileptic therapy in the patients in our study. Displacement of doxycycline from plasma protein by diphenylhydantoin or carbamazepine might to some extent contribute to the increased turnover of doxycycline, but not enough wholly to explain the shortening of the half life we found in our cases.

As well as an antiepileptic drug diphenylhydantoin is also increasingly used as an antiarhythmic drug, and carbamazepine is also given in cases of trigeminal neuralgia. Other antiepileptic drugs such as primidone, methoin, and paramethadione, which also induce drug metabolism (Remmer, 1972), may hasten the metabolism of doxycycline. Sulthiame, on the other hand, interferes with the metabolism of diphenylhydantoin to prolong its half life (Hansen et al., 1968; Richens and Houghton, 1973), so sulthiame is unlikely to indıce doxycycline metabolism.

Whether other tetracycline derivatives are affected in the same way as doxycycline remains to be seen. But when highly lipophilic tetracycline derivatives are given together with diphenylhydantoin or carbamazepine, or other drugs known to be inducers of drug metabolism, the serum tetracycline concentration should be watched to see that it does not fall below the minimum inhibitory level.
We thank the patients who volunteered to take part in this trial, and the nurses for their essential assistance. We are indebted to Pfizer Oy for support and to the National Research Council for Medical Sciences, Finland, for a grant.

\section{References}

Bennett, J. V., Brodie, J. L., Benner, E. J., and Kirby, W. M. M. (1966). Applied Microbiology, 14, 170.

Breckenridge, A., and Orme, M. (1971). Annals of the New York Academy of Sciences, 179, 421.

Breckenridge, A., Orme, M. L'E., Davies, L., Thorgeirsson, S. S., and Davies, D. S . (1973). Clinical Pharmacology and Therapeutics, 14, 514 Conney, A. H. (1967). Pharmacological Reviews, 19, 317.

Frey, H., and Yriänä, T. (1970). Scandinavian fournal of Clinical and Laboratory Investigation, 25, Suppl. No. 113, p. 90.

Hansen, J. M., Kristensen, M., and Skovsted, L. (1968). Epilepsia, 9, 17. Hansen, J. M., Kristensen, M., and Skovsted, L. (1968). Epilepsia, 9, 17. Pharmacology and Therapeutics, 12, 539.

Klinger, W., Bayerl, P., and Edel, H. (1970). In Progress in Antimicrobial and Anticancer Chemotherapy: Proceedings of Sixth International Congress of Chemotherapy, vol. 1 , p. 605, Baltimore, University Park Press.

Kohn, K. W. (1961). Analytical Chemistry, 33, 862

Neuvonen, P. J., and Penttilä, O. (1974). British Medical Fournal, 1, 535.

Prescott, L. F. (1973). Drugs, 5, 161.

Remmer, H. (1962). In Proceedings of First International Pharmacological Meeting, ed. B. Uvnäs, vol. 6, p. 235. Oxford, Pergamon.

Remmer, H. (1972). European fournal of Clinical Pharmacology, 5, 116.

Richens, A., and Houghton, G. W. (1973). Lancet, 2, 442.

Vendelin-Olesen, $\mathrm{O}$. (1969). Scandinavian fournal of Clinical and Laboratory Investigation, 23, 175.

\title{
Comparison of Effect of Two Induction Doses of Metho- hexitone on Infants Delivered by Elective Caesarean Section
}

\author{
ANITA HOLDCROFT, M. J. ROBINSON, H. GORDON, J. G. WHITWAM
}

British Medical fournal, 1974, 2, 472-475

\section{Summary}

Observations were made on 26 infants delivered by elective caesarean section under general anaesthesia. A standard anaesthetic technique was employed using a methohexitone, relaxant, nitrous oxide-oxygen sequence with regulated ventilation and the administration of papaveretum after clamping the umbilical cord. In 12 patients the induction dose of methohexitone was $1.4 \mathrm{mg} / \mathrm{kg}$ and in 14 it was reduced to $1.0 \mathrm{mg} / \mathrm{kg}$. There were no significant differences between the two groups in the clinical status of the mothers, in operative technique and timing, or in the value of $\mathrm{PO}_{2}, \mathrm{PCO}_{2}$, and $\mathrm{pH}$ in the umbilical cord venous blood.

The infants whose mothers received the lower dose of methohexitone were in better condition, as assessed by the number needing assisted ventilation, the time taken to establish regular respiration, the Apgar score, and the "Apgar minus colour" score.

Royal Postgraduate Medical School, London W12 0HS

ANITA HOLDCROFT, M.B., F.F.A. R.C.s., Senior Registrar, Department of Anaesthetics

M. J. ROBINSON, B.M., M.R.C.P., Neonatal Resident, Department of Child M. J. ROBINSON, B.M., M.R.C.P., Neonatal Resident, Department of Child H. GORDON, F.R.C.s., M.R.C.o.G., Senior Lecturer and Honorary Consultant, Department of Obstetrics

J. G. WHITWAM, F.F.A. R.C.S., M.R.C.P., Reader and Honorary Consultant, Department of Anaesthetics

\section{Introduction}

In clinical practice the induction dose of methohexitone for anaesthesia for caesarean section is either related to the patient's weight, and can vary from 0.7 to $1.8 \mathrm{mg} / \mathrm{kg}$ (Lee, 1965) without causing fetal depression, or it is given as a standard dose of $100 \mathrm{mg}$ (Sliom, 1962). Marshall (1964) suggested that up to 120 $\mathrm{mg}$ of methohexitone can be given without significant depression of the infant. The dose of methohexitone for any individual patient should avoid cardiorespiratory depression of the mother and fetus without allowing maternal awareness.

Within the range previously acceptable in clinical practice two induction doses $(1.4 \mathrm{mg} / \mathrm{kg}$ and $1.0 \mathrm{mg} / \mathrm{kg})$ were chosen. A maximum total dose was arbitrarily set at $120 \mathrm{mg}$ and up to this the dosage was based on the predelivery weight since an increase in body weight from any cause will usually increase drug requirement. Recovery of consciousness after a single dose of a short-acting barbiturate, however, is caused mainly by redistribution of the drug into lean body mass (Price, 1960).

\section{Patients and Methods}

SELECTION OF PATIENTS

Twenty-six otherwise healthy patients undergoing elective caesarean section were observed. The indication for operation was disproportion in 21 cases and malpresentation in five. None of the patients was in established labour at the time of operation, the membranes were intact, and a lower segment operation was performed in all cases. The first 12 patients received the higher dose of methohexitone $(1.4 \mathrm{mg} / \mathrm{kg})$ and the subsequent 14 the lower dose $(1.0 \mathrm{mg} / \mathrm{kg})$. The two groups were comparable in respect of maternal age, weight, haemoglobin, gestation period, and the weight of the babies (table I). 
TABLE I-Comparison of 26 Mothers and their Infants delivered by Caesarean Section, 12 of whom were induced with 1.4 mg/kg Methohexitone (High Dose) and 14 of whom were induced with $1.0 \mathrm{mg} / \mathrm{kg}$ (Low Dose). Results expressed as Means \pm S.D.

\begin{tabular}{|c|c|c|c|c|c|c|}
\hline & \multicolumn{4}{|c|}{ Maternal Values } & \multirow{2}{*}{ Gestation (Days) } & \multirow{2}{*}{ Infant Weight (g) } \\
\hline & Age (Years) & $\begin{array}{l}\text { Haemoglobin } \\
(\mathrm{g} / 100 \mathrm{ml})\end{array}$ & $\begin{array}{l}\text { Packed cell } \\
\text { Volume }(\%)\end{array}$ & $\begin{array}{l}\text { Predelivery } \\
\text { Weight (kg) }\end{array}$ & & \\
\hline $\begin{array}{l}\text { High-dose group } \\
\text { Low-dose group }\end{array}$ & $\begin{array}{l}29.0 \pm 6.1 \\
31.5 \pm 4.6\end{array}$ & $\begin{array}{l}12 \cdot 3 \pm 1 \cdot 0 \\
12 \cdot 4 \pm 1 \cdot 0\end{array}$ & $\begin{array}{l}37 \cdot 8 \pm 3 \cdot 0 \\
38 \cdot 7 \pm 2 \cdot 0\end{array}$ & $\begin{array}{r}73 \cdot 2 \pm 23.4 \\
71.1 \pm 7.7\end{array}$ & $\begin{array}{l}279.0 \pm 13.9 \\
271.8 \pm 5.5\end{array}$ & $\begin{array}{l}3,247 \pm 463 \\
3,532 \pm 590\end{array}$ \\
\hline
\end{tabular}

\section{ANAESTHETIC TECHNIQUE}

Magnesium trisilicate $15 \mathrm{ml}$ was given by mouth within 30 minutes of the operation. Premedication was restricted to 0.6 $\mathrm{mg}$ of atropine given either intramuscularly one hour before the operation or intravenously immediately before induction of anaesthesia. Atropine was used in preference to hyoscine to reduce the incidence of excitatory phenomena during the administration of methohexitone (Dundee and Moore, 1961; Dundee et al., 1961). No other drugs were given before the operation.

Each patient was placed in the supine position on the operating table in theatre. Pulse rate and blood pressure were recorded. After setting up an intravenous infusion of Hartmann's solution the patient was preoxygenated for five minutes. The calculated dose of methohexitone was injected intravenously as a $1 \%$ solution, followed by suxamethonium $1 \mathrm{mg} / \mathrm{kg}$. Cricoid pressure was applied at the start of the injection of methohexitone and continued until an endotracheal tube had been passed and its cuff inflated. The patients were ventilated mechanically with a mixture of $33 \%$ oxygen in nitrous oxide. For each case a Manley ventilator (Blease Anaesthetics, Chesham, Bucks) was used with similar non-distensible tubing. Half the patients in each group were ventilated with a fresh gas flow of $6-71 . / \mathrm{min}$ and the remainder at $12-14 \mathrm{l} . / \mathrm{min}$.

On return of muscle tone tubocurarine was given in doses from 25 to $40 \mathrm{mg}$. The induction-to-delivery time was noted. A section of umbilical cord was isolated between clamps before the onset of breathing in the infant, and an umbilical venous blood sample was drawn into a plastic heparinized syringe and kept in ice until analysed. After delivery ergometrine $0.5 \mathrm{mg}$ and papaveretum in doses from 5 to $10 \mathrm{mg}$ were given intravenously. Subsequently further doses of relaxant and papaveretum were given when required.
The mothers were interviewed immediately after the operation and in the ward the next day. They were asked to recall when they became anaesthetized, the first thing they remembered on awaking, and any awareness of dreaming or other sensations during the operation.

\section{ASSESSMENT OF THE CHILD'S CONDITION}

The general condition of the child at birth was noted by an anaesthetist. The infant was assessed one minute after delivery by a paediatrician, and the Apgar and Apgar minus colour (A-C) scores were noted. The time to the onset of regular respiration was recorded. The paediatricians assessing the infants had no information about the anaesthetic management of the mothers.

The measurement of $\mathrm{pH}, \mathrm{Po}_{2}$, and $\mathrm{PCO}_{2}$ was made on cord blood using an I.L.313 electrode system (Instrument Laboratory Inc., Altrincham, Cheshire). All measurements were made within 30 minutes of sampling.

\section{Results}

Mean values of $\mathrm{PCO}_{2}, \mathrm{pH}$, and $\mathrm{PO}_{2}$ of the cord blood of the infants are shown in table II. There was no significant difference between those whose mothers received $1.4 \mathrm{mg} / \mathrm{kg}$ and those whose mothers received $1.0 \mathrm{mg} / \mathrm{kg}$ of methohexitone. The one minute Apgar score and A-C score are also shown in the table. Three infants in the high-dose group had an Apgar score of 8 or over compared with 11 in the low-dose group. There was a significant difference between the Apgar and A-C scores as determined by the Mann-Whitney $U$ test $(P<0.01)$. There was no significant relation between either the A-C score or the time

TABLE II-Acid Base and Clinical Status of Infants in High-dose and Low-dose Groups

\begin{tabular}{|c|c|c|c|c|c|c|c|c|}
\hline $\begin{array}{l}\text { Case } \\
\text { No. }\end{array}$ & $\underset{(\mathrm{mm} \mathrm{Hg})}{\mathrm{PCO}_{2}}$ & $\mathrm{pH}$ & $\underset{(\mathrm{mm} \mathrm{Hg})}{\mathrm{PO}_{2}}$ & $\begin{array}{l}\text { Apgar Score } \\
\text { (at } 1 \text { min) }\end{array}$ & $\begin{array}{l}\text { A-C Score } \\
\text { (at } 1 \text { min) }\end{array}$ & $\begin{array}{c}\text { Time to } \\
\text { Regular } \\
\text { Respiration (min) }\end{array}$ & Intubated & $\begin{array}{c}\text { Induction-to- } \\
\text { Delivery } \\
\text { Time (min) }\end{array}$ \\
\hline $\begin{array}{r}1 \\
2 \\
3 \\
4 \\
5 \\
6 \\
7 \\
8 \\
9 \\
10 \\
11 \\
12 \\
\pm \text { S.D. }\end{array}$ & $\begin{array}{c}54 \\
43 \\
41 \\
53 \\
45 \\
43 \\
46 \\
60 \\
43 \\
42 \\
34 \\
45 \cdot 8 \pm 7 \cdot 2\end{array}$ & $\begin{array}{c}\mathbf{7 . 3 0} \\
\mathbf{7 . 2 5} \\
\mathbf{7 . 3 7} \\
\mathbf{7 \cdot 2 9} \\
\mathbf{7 . 2 8} \\
\mathbf{7 . 3 0} \\
\mathbf{7 . 3 6} \\
\mathbf{7 . 3 3} \\
\mathbf{7 . 3 3} \\
\mathbf{7 . 4 2} \\
\mathbf{7 . 4 3} \\
\mathbf{7 . 3 3} \pm 0.06\end{array}$ & $\begin{array}{c}18 \\
32 \\
27 \\
24 \\
21 \\
29 \\
10 \\
26 \\
18 \\
20 \\
22.5 \pm 6.4\end{array}$ & $\begin{array}{c}\text { igh-dose Group } \\
2 \\
4 \\
10 \\
10 \\
4 \\
4 \\
10 \\
1 \\
4 \\
7 \\
7 \\
7\end{array}$ & $\begin{array}{l}2 \\
3 \\
8 \\
8 \\
4 \\
3 \\
8 \\
1 \\
4 \\
6 \\
5 \\
5\end{array}$ & $\begin{array}{r}25 \\
19 \\
<1 \\
<1 \\
5 \\
15 \\
<1 \\
10 \\
4 \\
9 \\
2 \\
10\end{array}$ & $\begin{array}{l}\text { Yes } \\
\text { Yes } \\
\text { No } \\
\text { No } \\
\text { Yes } \\
\text { Yes } \\
\text { No } \\
\text { Yes } \\
\text { Yes } \\
\text { Yes } \\
\text { No } \\
\text { Yes }\end{array}$ & $\begin{array}{r}8 \\
10 \\
9 \\
27 \\
21 \\
10 \\
11 \\
9 \\
12 \\
14 \\
10 \\
12 \\
12 \cdot 8 \pm 5 \cdot 6\end{array}$ \\
\hline \multicolumn{9}{|c|}{ Low-dose Group } \\
\hline $\begin{array}{l}13 \\
14 \\
15 \\
16 \\
17 \\
18 \\
19 \\
20 \\
21 \\
22 \\
23 \\
24 \\
25 \\
26\end{array}$ & $\begin{array}{l}53 \\
46 \\
46 \\
51 \\
46 \\
48 \\
37 \\
44 \\
55 \\
53 \\
65 \\
60 \\
33\end{array}$ & $\begin{array}{l}7 \cdot 35 \\
7 \cdot 38 \\
7 \cdot 37 \\
7 \cdot 32 \\
7 \cdot 36 \\
7 \cdot 28 \\
7 \cdot 37 \\
7 \cdot 39 \\
7 \cdot 34 \\
7 \cdot 36 \\
7 \cdot 33 \\
7 \cdot 36 \\
7 \cdot 38 \\
\end{array}$ & $\begin{array}{l}31 \\
23 \\
19 \\
11 \\
27 \\
17 \\
28 \\
31 \\
18 \\
16 \\
19 \\
23\end{array}$ & $\begin{array}{r}10 \\
10 \\
10 \\
7 \\
10 \\
10 \\
10 \\
10 \\
7 \\
10 \\
4 \\
8 \\
10 \\
10\end{array}$ & $\begin{array}{l}8 \\
8 \\
8 \\
5 \\
8 \\
8 \\
8 \\
8 \\
5 \\
8 \\
4 \\
6 \\
8 \\
8 \\
\end{array}$ & $\begin{array}{r}<1 \\
<1 \\
<1 \\
4 \\
<1 \\
<1 \\
<1 \\
<1 \\
21 \\
<1 \\
4 \\
17 \\
<1 \\
<1 \\
\end{array}$ & $\begin{array}{l}\text { No } \\
\text { No } \\
\text { No } \\
\text { No } \\
\text { No } \\
\text { No } \\
\text { No } \\
\text { No } \\
\text { No } \\
\text { No } \\
\text { Yes } \\
\text { No } \\
\text { No } \\
\text { No } \\
\end{array}$ & $\begin{array}{r}17 \\
11 \\
10 \\
10 \\
11 \\
6 \\
7 \\
10 \\
11 \\
10 \\
16 \\
7 \\
4 \\
20\end{array}$ \\
\hline $\begin{array}{l}\text { Mean } \pm \text { S.D. } \\
\text { Significance }\end{array}$ & $\underset{\mathrm{N} . \mathrm{S}}{49 \cdot 0 \pm 8 \cdot 7}$ & $\begin{array}{c}7.35 \pm 0.03 \\
\text { N.S }\end{array}$ & $\stackrel{21 \cdot 9 \pm 0.3}{\text { N.S }}$ & & & & & $\underset{N}{10 \cdot 7 \pm 4 \cdot 4}$ \\
\hline
\end{tabular}

A-C = Apgar minus colour. 
to the onset of regular respiration and the induction-to-delivery interval in either group (figs. 1 and 2).

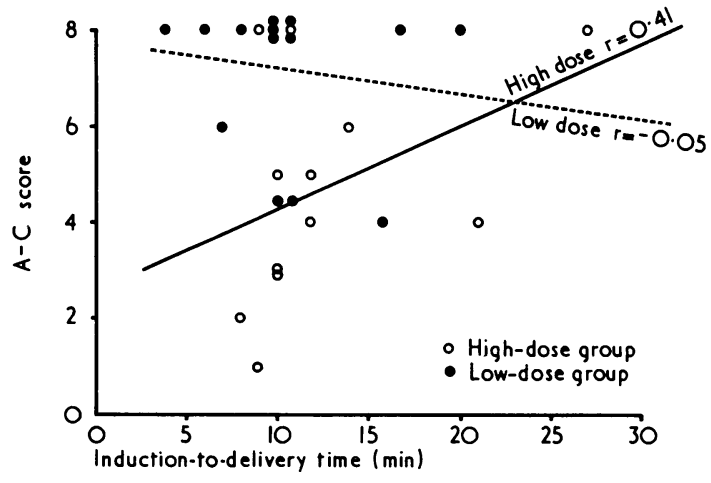

FIG. 1-Relation between Apgar minus colour (A-C) score and induction-to-delivery time in patients receiving $1.4 \mathrm{mg}$ $\mathrm{kg}$ methohexitone (high dose) and $1.0 \mathrm{mg} / \mathrm{kg}$ (low dose).

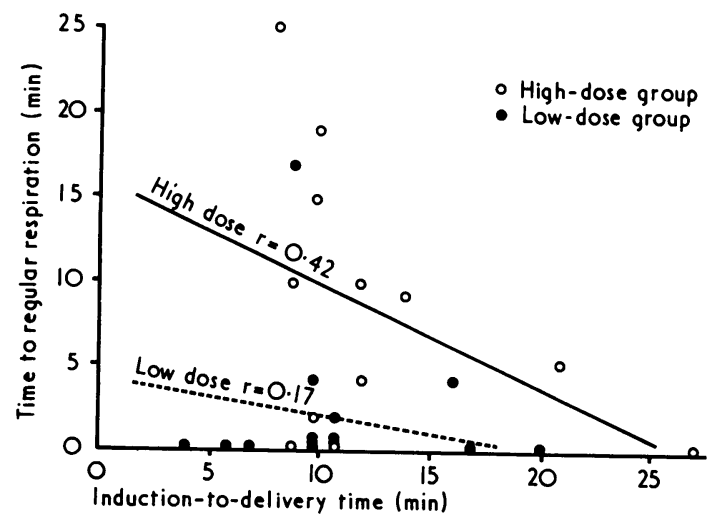

FIG. 2-Relation between time to onset of regular respiration and induction-to-delivery time in patients receiving $1.4 \mathrm{mg}$ $\mathrm{kg}$ methohexitone (high dose) and $1.0 \mathrm{mg} / \mathrm{kg}$ (low dose).

In the group receiving $1.4 \mathrm{mg} / \mathrm{kg}$ methohexitone seven babies took five minutes or longer to establish regular respiration compared with only one in the group where $1.0 \mathrm{mg} / \mathrm{kg}$ was given. Eight of the 12 infants in the high-dose group needed intubation and intermittent positive pressure ventilation compared with only one of the 14 receiving the low dose. Again a significant difference was apparent between the two groups $(\mathbf{P}<0.01)$.

There was no maternal awareness. In the low-dose group patients could not recall any events occurring during the operation nor was there any dreaming. Predelivery recollections were limited to the journey to the theatre and the period of preoxygenation. No long-term problems occurred in the infants of either group.

\section{Discussion}

A satisfactory general anaesthetic technique for caesarean section should achieve minimal respiratory and cardiovascular depression of mother and fetus and at the same time prevent maternal awareness. In equipotent doses methohexitone causes less cardiovascular depression and is associated with more rapid recovery than thiopentone. The subject has been recently reviewed by Whitwam (1972), and the evidence currently available suggests that methohexitone is the induction agent of choice for caesarean section. One possible disadvantage in using methohexitone in preference to thiopentone is the risk of awareness during surgery. On retrospective questioning there was no recall of events or unpleasant dreams or experiences in either group of patients. Only a limited number of patients were studied, however, and in most the induction-to-delivery interval was relatively short, and papaveretum was given afterwards. The incidence of awareness during caesarean section varies from $2 \%$ to $5 \%$ in different reports (Wilson, 1969; Crawford, 1962), and though it seems to be minimal in this study it could become higher if the induction-to-delivery interval were prolonged or if anaesthesia were maintained in the postdelivery period without the addition of drugs to supplement nitrous oxide.

Standard doses of induction agents are often advocated for caesarean section with no reference to the weight or physical status of the mother (Moir, 1970; Sliom, 1962; Crawford, 1972). It would be more logical to expect patient requirements to be variable, and on occasions a standard dose of intravenous agent might cause fetal depression in otherwise uncomplicated cases.

Our results show that for each of the methods used in assessment (number needing assisted respiration, time to establish regular respiration. Apgar score, and A-C score) the infants of mothers receiving $1.0 \mathrm{mg} / \mathrm{kg}$ of methohexitone were in better condition at birth than those receiving the higher dose $(1.4 \mathrm{mg} / \mathrm{kg})$. In both groups other aspects of management were similar.

Crawford (1972) showed a tendency for low A-C scores to be associated with an induction-to-delivery interval of less than 10 minutes and suggested that this was most likely to be due to "drug-induced" depression. In our patients, however, there was no significant correlation between the A-C score and induction-to-delivery interval in either group, but ours was a relatively small group of patients and possibly a correlation of fetal condition with induction-to-delivery time could occur in a larger series. Hence, in the present study a time-related druginduced effect on fetal condition might have been expected particularly in the high-dose group.

On occasions after elective caesarean section when no fetal or maternal abnormality would be expected an infant is delivered with a low Apgar score. Various modifications of technique have been recommended to prevent otherwise unexplained fetal depression. Such modifications include the use of a $50-60 \%$ mixture of oxygen in nitrous oxide with the addition of a volatile anaesthetic agent, (Moir, 1970; Rorke, 1968), the use of lateral tilt to avoid compression of the inferior vena cava (Crawford, 1972), the avoidance of over-ventilation and high inflation pressures (Scott, 1969), and an attempt to achieve an optimum induction-to-delivery time (Crawford, 1972; Lee, 1965). The fact that the cord blood gases were similar in our two groups would suggest that the observed differences in conditions of the infants were not due to factors such as maternal ventilation and haemodynamics. Coleman (1967) has observed that in the neonate poor clinical condition at birth may not correlate with the acid base status and that facts of significance in the aetiology of fetal depression may not be reflected in blood gas analysis at the time of delivery.

Barbiturates cross the placenta (McKechnie and Converse, 1955), and Marshall (1964) showed that the amount of methohexitone in umbilical venous blood correlated directly with the maternal dosage. Hitherto it has been widely assumed that a "sleep" dose of barbiturate given to the mother has minimal effect on the fetus. Methohexitone has been used in doses ranging from 0.75 to $1.8 \mathrm{mg} / \mathrm{kg}$ with apparently no significant fetal depression (Lee, 1965). Marshall also suggested that fetal depression would not be a problem with doses up to $120 \mathrm{mg}$. Because of an implied difficulty in assessing individual requirements a "standard" dose of barbiturate is often given rapidly for a so-called "crash induction."

Sunshine et al. (1966) showed that blood levels of methohexitone decay rapidly after a single intravenous dose. Marshall (1964), however, found that the cord blood level of an intravenous barbiturate given to the mothers was maximal within three to four minutes, but that after larger doses-that is, $85 \mathrm{mg}$-of 
methohexitone the peak level in cord blood was maintained for up to seven minutes. In the present study the considerable difference between the two groups of infants strongly suggests a greater residual barbiturate effect in the high-dose group. The results also show that within the currently acceptable clinical usage of methohexitone the dose used to induce anaesthesia for caesarean section may be a significant factor in the aetiology of some cases of neonatal depression.

It would seem rational to relate the induction dose of methohexitone to the physical status of the mother, and the maternal weight before delivery is the most readily accessible measurement. We recommend that the dose of methohexitone used to induce anaesthesia for caesarean section should be of the order of $1 \mathrm{mg} / \mathrm{kg}$.

We thank all members of the departments of anaesthetics, obstetrics, and child health at Hammersmith Hospital who co-operated in this study, Miss Aviva Petrie of the department of statistics at the Post- graduate Medical School for statistical advice, and Miss Karen Gorman for secretarial help.

\section{References}

Coleman, A. J. (1967). Lancet, 1, 813.

Crawford, J. S. (1962). British fournal of Anaesthesia, 34, 417.

Crawford, J. S., Burton, M., and Davies, P. (1972). British fournal of Anaesthesia, 44, 477.

Dundee, J. W. and Moore, J. (1961). Anaesthesia, 16, 194

Dundee, J. W., Riding, J. E., Barron, D. W., and Nicholl, R. M. (1961) British fournal of Anaesthesia, 33, 296.

Lee, P. F. S. (1965). Acta Obstetrica et Gynecology Scandinavica, 44, 458. Marshall, J. R. (1964). Obstetrics and Gynecology, 23, 589.

McKechnie, F. B., and Converse, J. G. (1955). American fournal of Obstetrics and Gynecology, 70, 639.

Moir, D. D. (1970). British fournal of Anaesthesia, 42, 136

Price, H. L. (1960). Anaesthesiology, 21, 40

Rorke, M. J., Davey, D. A., and DuToit, H. J. (1968). Anaesthesia, 23, 585

Scott, D. B., Lees, M. M., Davie, I. T., Slawson, K. B., and Kerr, M. G. (1969). British fournal of Anaesthesia, 41, 489.

Sliom, C. M., Frankel, L., and Holbrook, R. A. (1962). British fournal of Anaesthesia, 34, 316.

Sunshine, I., Whitwam, J. G., Fike, W. W., Finkle, B., and Le Beau, J. (1966). British fournal of Anaesthesia, 38, 23.

Whitwam, J. G. (1972). In Das Ultrakurznarkoticum Methohexital, ed Charlotte Lehmann, p. 2. Berlin, Springer-Verlag.

Wilson, J., and Turner, D. J. (1969). British Medical fournal, 1, 280.

\title{
Fenoprofen in Treatment of Osteoarthrosis of Hip and Knee
}

\author{
J. A. WOJTULEWSKI, F. DUDLEY HART, E. C. HUSKISSON
}

British Medical fournal, 1974, 2, 475-476

\section{Summary}

Two studies on 41 patients with osteoarthrosis of the hip or knee have shown fenoprofen-a compound with analgesic and anti-inflammatory properties-to be an effective addition to the drug treatment of these conditions. It was found to be superior to paracetamol but no statistically significant difference was shown in a comparison with phenylbutazone.

\section{Introduction}

Fenoprofen (DL-2-(3-phenoxyphenyl)propionic acid) has demonstrable analgesic, anti-inflammatory, and antipyretic properties in animals (Nickander et al., 1971). Recently it has been shown to be effective and well tolerated in patients with rheumatoid arthritis (Fries and Britton, 1973; Huskisson et al., 1974). We have assessed its value in osteoarthrosis of the hip and knee.

\section{Study 1}

A total of 24 patients with osteoarthrosis of the hip or knees were admitted to a double-blind crossover study of single doses of fenoprofen $600 \mathrm{mg}$, paracetamol $990 \mathrm{mg}$, and placebo. Treatments were given in pairs, each patient comparing every possible pair. A patient might therefore receive fenoprofen on day 1 of the study, paracetamol on day 2 , fenoprofen on day 4 , placebo on day 5 , paracetamol on day 7, and placebo on day 8 . On the third and sixth days no trial analgesics were given. The com-

\section{Westminster Hospital, London SW1P 2AP}

J. A. WOJTULEWSKI, M.B., M.R.C.P., Senior Research Registrar

F. DUDLEY HART, M.D., F.R.C.P., Consultant Physician

St. Bartholomew's Hospital, London EC1A 7BE

E. C. HUSKISSON, M.B., M.R.C.P., Senior Registrar pounds were supplied in pink or white capsules so that each of a pair of treatments appeared to be different; one patient might compare pink fenoprofen with white placebo, while another compared white fenoprofen with pink placebo. The order of administration was randomized in a latin square design balanced for order and colour of the capsules. No other medication was allowed for six hours after administration of the test analgesics.

The analgesics were taken at about the same time each day when pain was either severe or moderately severe. After taking the capsules the patients were asked to record pain relief hourly for six hours using a simple scale consisting of no pain relief and slight, moderate, and complete pain relief. After each pair of treatments preference was recorded.

The results are shown in the chart.

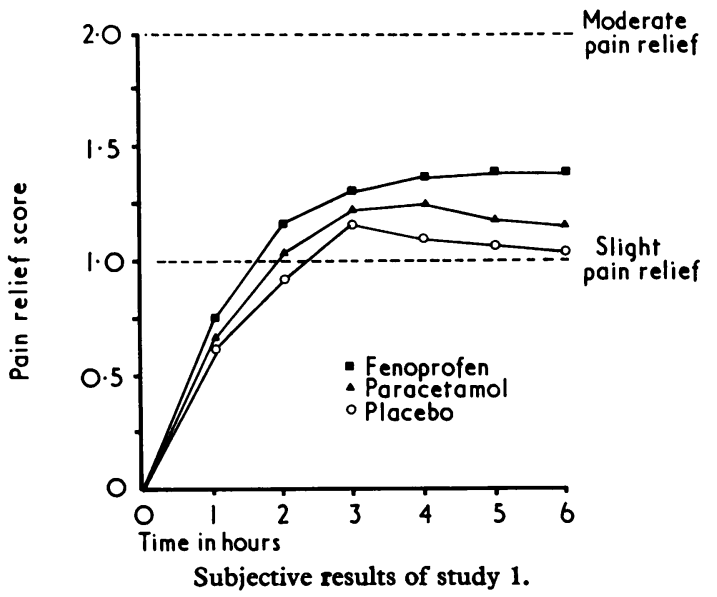

Study 2

Fenoprofen $2 \mathrm{~g}$ daily was compared with phenylbutazone $300 \mathrm{mg}$ daily on a double-blind crossover basis, each drug being given for 14 days, with an intercalated double-blind crossover 